ISSN 1392-3196

Zemdirbyste-Agriculture, vol. 100, No. 1 (2013), p. 91-98

UDK 635.9:631.67:631.526 / DOI 10.13080/z-a.2013.100.012

\title{
The effects of water stress on evapotranspiration and leaf temperatures of two olive (Olea europaea L.) cultivars
}

\author{
Gökhan ÇAMOĞLU \\ Canakkale Onsekiz Mart University \\ 17020 Canakkale, Turkey \\ E-mail: camoglu@comu.edu.tr
}

\begin{abstract}
The evapotranspiration (ET) and leaf temperatures of two olive (Olea europaea L.) cultivars 'Ayvalık' and 'Gemlik' were studied comparatively in fully-irrigated and water-stressed plants. The pot experiment was conducted under field conditions in 2009 and 2010. The experiment consisted of 4 treatments: 1) non water-stressed, 2) mild waterstressed, 3) moderate water-stressed, and 4) fully water-stressed. Leaf temperature (Tc) and ambient air temperature (Ta) of each seedling were measured at midday with an infrared thermometer and psychrometer respectively, and Tc-Ta was assessed. It was found that the irrigation water requirement of 'Gemlik' olive seedlings exceeded that of 'Ayvalık' olive seedlings. Tc-Ta was highest in the fully water-stressed treatment and lowest in the non water-stressed treatment for both olive cultivars. In all treatments, the Tc-Ta of 'Gemlik' was higher than that of 'Ayvalık'. The relationship between Tc-Ta and ET was linear and the coefficients of determination $\left(\mathrm{R}^{2}=0.72\right.$ 0.74 for 'Ayvalık', $\mathrm{R}^{2}=0.62-0.72$ for 'Gemlik' according to the analysis of linear regression) were statistically significant at $p<0.001$ for both cultivars. The study showed that leaf temperature changed depending on ET in both olive cultivars and that an infrared thermometer can be used for measuring daily ET in olive seedlings.
\end{abstract}

Key words: 'Ayvalık', 'Gemlik', irrigation, leaf temperature, olive, water stress.

\section{Introduction}

Turkey is a major global olive producer, ranking fourth after Spain, Italy and Greece according to 2009 data (FAO, 2011). 'Ayvalık' and 'Gemlik' olive trees compose $20 \%$ and $11 \%$ respectively of olive trees in Turkey, with Memecik olive trees being the most common (45\%) (Öztürk et al., 2009). Approximately $63 \%$ of olive grain production in Turkey is met from the Aegean region where 'Ayvalık', 'Memecik', 'Domat', 'Erkence', 'Uslu', 'Çakır' and 'Çilli' olive cultivars are common (Canözer, 1991). In addition to these, the 'Gemlik' olive cultivar growing in the Marmara region has rapidly spread in the districts of Akhisar, Salihli-Manisa, İzmir and Karacasu-Aydın in recent years (Arsel, Sefer, 2006). 'Gemlik' is the most important cultivar in the Marmara region that meets a substantial proportion of olive grain production in Turkey. $80 \%$ and $20 \%$ of 'Gemlik' olives are consumed as black table olives and olive oil in the region, respectively (Canözer, 1991).

In Turkey, olive growing is often confined to slopes or fairly rugged land and occupies large areas of mountains and hills where plants are frequently subjected to high temperatures and water scarcity (Akkuzu et al., 2010). Olive farming in these areas can be affected by the amount of rainfall. When there is no rain for a long time, olive trees suffer exposure to water stress. Olive trees growing in arid and semi-arid regions especially will be subjected to greater water stress due to an increase in crop water consumption as a result of global climate change. For this reason, determining water consumption and responses to water stress in olive plants, and the development of stress-resistant varieties, is very important. Metheney et al. (1994), Xiloyannis et al. (1999), Chartzoulakis et al. (2000), and Aşık et al. (2010) have indicated that olive plants were affected by water stress.

Fuchs and Tanner (1966) reported that it is well-known from energy balance considerations that leaf temperature varies with evaporation from leaves and hence is a function of stomata conductance (Jones, 1999). Leaf temperature is a physiological trait that can be used for monitoring plant water status (Jimenez-Bello et al., 2011). In general, water stress causes stomata closure in plants, and this leads to higher leaf temperature (Sdoodee, Kaewkong, 2006).

In this study, changes in evapotranspiration (ET) and leaf temperature of 'Ayvalık' and 'Gemlik' olive seedlings was evaluated by comparing at nonstressed and different levels of water stress. Estimation of ET was investigated using the difference between leaf temperature (Tc) and ambient air temperature (Ta). For this purpose, the experiment consisted of four irrigation treatments, namely, full irrigation and three water-stressed treatments. ET and Tc-Ta values of the olive seedlings were measured during the experiment. 


\section{Materials and methods}

Study site. The pot experiment was conducted under field conditions in Bornova Olive Research Institute (Izmir, Turkey; 38 $43^{\prime} \mathrm{N}, 27^{\circ} 25^{\prime} \mathrm{E} ; 20 \mathrm{~m}$ a.s.1.) in the summer of 2009 and 2010. In the study, two-yearold olive (Olea europaea L., cvs 'Ayvalık' and 'Gemlik') seedlings were used as crop material in both years.
The climate in the research area is typically Mediterranean characterized by hot, dry summers and mild, rainy winters. Mean annual rainfall is about $692 \mathrm{~mm}$ and the warmest months are July and August. Meteorological data in the research area for 2009 and 2010 are given in Table 1.

Table 1. Meteorological data in research area for 2009 and 2010

\begin{tabular}{|c|c|c|c|c|c|}
\hline \multirow{2}{*}{ Year } & \multirow{2}{*}{ Climate parameters } & \multicolumn{4}{|c|}{ Month } \\
\hline & & 05 & 07 & 08 & 09 \\
\hline \multirow{5}{*}{2009} & Mean temperature ${ }^{\circ} \mathrm{C}$ & 26.2 & 28.9 & 27.8 & 23.2 \\
\hline & Mean relative humidity $\%$ & 45.7 & 45.7 & 42.7 & 56.6 \\
\hline & Total rainfall mm & 9.2 & 0 & 0 & 51.2 \\
\hline & Mean wind velocity $\mathrm{m} \mathrm{s}^{-1}$ & 3.1 & 3.5 & 3.2 & 2.8 \\
\hline & Evaporation mm month ${ }^{-1}$ & 255.6 & 277.8 & 266.8 & 159.7 \\
\hline \multirow{5}{*}{2010} & Mean temperature ${ }^{\circ} \mathrm{C}$ & 25.5 & 28.8 & 30.2 & 24.9 \\
\hline & Mean relative humidity $\%$ & 51.3 & 47.4 & 47.6 & 50.7 \\
\hline & Total rainfall $\mathrm{mm}$ & 76.3 & 0 & 0 & 12.3 \\
\hline & Mean wind velocity $\mathrm{m} \mathrm{s}^{-1}$ & 2.7 & 3.3 & 2.9 & 2.7 \\
\hline & Evaporation mm month ${ }^{-1}$ & 201.2 & 251.0 & 246.9 & 160.1 \\
\hline
\end{tabular}

Experimental design. The pot experiments consisted of four irrigation-level treatments with three replicates in a randomized block design. The treatments are given in Table 2 .

Uniform (in appearance) olive seedlings were transferred to plastic pots with a volume of 12 litres (diameter of evaporation surface $=\varnothing 28$ ) on 8 July 2009 and 26 June 2010. Turf was used as the growing medium. $13.8 \mathrm{~g} \mathrm{KNO}_{3}, 11.7 \mathrm{~g} \mathrm{MAP,} 12.5 \mathrm{~g} \mathrm{NH}_{4} \mathrm{NO}_{3}$ and $0.5 \mathrm{~g}$ micro-nutrients per pot were applied to all the treatments. Half of the $\mathrm{NH}_{4} \mathrm{NO}_{3}$ was applied one month after starting the experiment. The experiments lasted for approximately two months in both years.

Table 2. Treatments in pot experiment

Treatment
I-100 (non water-stressed)
I-75 (mild water-stressed)
I-50 (moderate water-stressed)
I-0 (fully water-stressed)
Calculationofamountofirrigation waterapplied
and evapotranspiration. The water holding capacity (pot
capacity) of each pot was determined at the beginning
of the experiment. Pots were initially saturated with tap
water and covered in order to prevent evaporation. The
water content of the pots after the drainage stopped was
assumed to be pot capacity (W $\mathrm{PC}_{\text {PC } \text { ). In this case, the pot }}$
capacity weights were determined as 11.0 kg in 2009 and
12.5 kg in 2010. Deficit irrigation treatments started two
days after pot capacity determination (i.e. 12 July 2009
and 30 June 2010). The irrigation interval was two days.
Each pot was weighed before each irrigation event. The
amount of irrigation water was determined by weighing
the pots (W) just before irrigation. The irrigation water
(I) applied to I-100 treatment was calculated according
to eq. (1). The deficit irrigation water amounts were
determined as indicated in Table 1 :

Explanation

lack of moisture in turf completed to pot capacity

$75 \%$ of water given to I-100

$50 \%$ of water given to I- 100

non-irrigated

$$
I=\frac{W_{P C}-W}{\rho_{w}}
$$

The amount of evapotranspiration was calculated using the water balance method (James, 1988) (eq. 2):

$$
E T=\frac{W_{1}+I+P-W_{2}}{\rho_{w}}
$$

where $\mathrm{W}_{\mathrm{PC}}$ and $\mathrm{W}$ are pot capacity weight $(\mathrm{kg})$ and pot weight (W) just before irrigation, respectively; ET is the amount of evapotranspiration in a pot $\left(\mathrm{L} \mathrm{pot}^{-1}\right)$, $\mathrm{W}_{1}$ and $\mathrm{W}_{2}$ are the pot weights $(\mathrm{kg})$ just before $\mathrm{n}^{\text {th }}$ and $(\mathrm{n}+1)^{\text {th }}$ irrigation, respectively, I and $\mathrm{P}$ are amounts of applied water and rainfall $(\mathrm{kg})$ respectively, and $\rho_{w}$ is water bulk density $\left(1 \mathrm{~kg} \mathrm{~L}^{-1}\right)$.

Since the leaching fraction was taken as zero, the amount of drainage was not included in eq. 1. 
Measurement of leaf temperature and ambient air temperature. Leaf temperatures $(\mathrm{Tc})$ were measured at midday using a hand-held infrared thermometer "Testo 845 " ("Testo AG", Germany) at an emissivity of 0.98 and a spectral response range of 8-14 $\mu \mathrm{m}$. On the days when the measurements were taken, the weather was completely cloud-free and sunny. The measurements were made on five leaves, which were sun-exposed on all plants, in three replications and then averaged. Ambient air temperatures (Ta) were obtained from a psychrometer. Psychrometer measurements were taken in a shaded location about $1.5 \mathrm{~m}$ above the ground. The difference between leaf temperature and air temperature was assessed as Tc-Ta.

Wind velocity was measured by means of a thermal anemometer "Testo 425" (Testo AG", Germany) at $2 \mathrm{~m}$ above the ground. When wind velocity was higher than $2 \mathrm{~m} \mathrm{~s}^{-1}$ during the day, leaf temperatures were not measured.

Statistical analysis. SPSS 13.0 program was used to carry out statistical analysis. The data were subjected to analysis of variance (PROC ANOVA and PROC $G L M)$, means were compared using Duncan's Test, and significance was set at $P<0.05$. Linear regression analysis was performed to determine the relationship between Tc-Ta and ET.

\section{Results and discussion}

Amounts of irrigation water (I) applied. After the olive seedlings had been transferred to pots, all pots were initially irrigated to pot capacity. Subsequent irrigations were made at intervals of two days according to the treatment. The first and last days of the irrigations according to the treatments were 192 day of year $\left(\mathrm{DOY}_{192}\right)$ and $\mathrm{DOY}_{250}$ respectively in 2009 , and DOY ${ }_{180}$ and DOY ${ }_{242}$ respectively in 2010 for both olive cultivars. Total amounts of irrigation water applied to the 'Ayvalık' and 'Gemlik' olive seedlings during the experiment are given in Table 3 .

Table 3. Total amounts of irrigation water (I) applied $\left(\mathrm{L} \operatorname{pot}^{-1}\right)$ per treatment to 'Ayvalık' and 'Gemlik' olive seedlings

\begin{tabular}{lccccc}
\hline \multirow{2}{*}{ Cultivar } & Year & \multicolumn{3}{c}{ Treatment } \\
\cline { 3 - 6 } & & $\mathrm{I}-100$ & $\mathrm{I}-75$ & $\mathrm{I}-50$ & $\mathrm{I}-0$ \\
'Ayvalık' & 2009 & $38.89 \mathrm{~A}$ & $30.87 \mathrm{~B}$ & $22.91 \mathrm{C}$ & $6.92 \mathrm{D}$ \\
& 2010 & $42.77 \mathrm{~A}$ & $34.06 \mathrm{~B}$ & $25.34 \mathrm{C}$ & $7.92 \mathrm{D}$ \\
& Mean & $40.83 \mathrm{Ab}$ & $32.46 \mathrm{Bb}$ & $24.13 \mathrm{Cb}$ & $7.42 \mathrm{Dns}$ \\
\hline \multirow{2}{*}{ 'Gemlik' } & 2009 & $42.17 \mathrm{~A}$ & $33.41 \mathrm{~B}$ & $24.43 \mathrm{C}$ & $6.92 \mathrm{D}$ \\
& 2010 & $46.87 \mathrm{~A}$ & $37.13 \mathrm{~B}$ & $27.39 \mathrm{C}$ & $7.92 \mathrm{D}$ \\
& Mean & $44.52 \mathrm{Aa}$ & $35.27 \mathrm{Ba}$ & $25.91 \mathrm{Ca}$ & $7.42 \mathrm{Dns}$ \\
\hline
\end{tabular}

Note. Capital letters refer to differences between irrigation treatments; lower letters refer to differences between cultivars.

While total amounts of irrigation water (I) applied to the 'Ayvalık' olive cultivar were between 6.92 and $42.77 \mathrm{~L} \mathrm{pot}^{-1}$ by year, they were between 7.42 and $40.83 \mathrm{~L}_{\text {pot }}{ }^{-1}$ when averaged across both years. These values were 7.42-40.83 and 7.42-46.87 $\mathrm{L} \mathrm{pot}^{-1}$ respectively for the 'Gemlik' olive cultivar. All treatments were statistically different from each other in both cultivars. Comparing the treatments of each cultivar, total amounts of irrigation water of other treatments except for I-0 in the 'Ayvalık' were lower and statistically different from the 'Gemlik' cultivar. Also, the cultivar $\times$ treatment interaction was statistically significant according to GLM test. Although the experimental duration was the same for both 'Ayvalık' and 'Gemlik' in both years, the total amounts of irrigation water applied in the second year were higher than in the first year. This is probably due to the fact that the experiment in the second year was started in June, which is cooler than July. In addition, differences in climate between the two years can be said to have had an impact on this change (Table 1).

When the total irrigation water applied to the olive seedlings was examined, more was applied to 'Gemlik' than 'Ayvalık' in both years. Accordingly, it can be said that 'Gemlik' olive seedlings needed more water than 'Ayvalık'.
Evapotranspiration (ET) of olive seedlings. Total ET values of 'Ayvalık' and 'Gemlik' olive seedlings are given in Table 4.

While the total ET amounts of the 'Ayvalık' olive cultivar ranged between 6.12 and $34.89 \mathrm{~L} \mathrm{pot}^{-1}$ over the two experimental years, they were between 6.16 and 33.29 $\mathrm{L} \mathrm{pot}^{-1}$ when averaged across both years. These values were 5.14-38.95 and 5.39-37.02 $\mathrm{L}$ pot $^{-1}$ respectively for the 'Gemlik' olive cultivar. Total ET values of all treatments were statistically different from each other in both cultivars. Comparing the treatments of each cultivar, total ET of other treatments except for I-0 in the 'Ayvalık' was lower and statistically different from the 'Gemlik' cultivar. Also, the cultivar $\times$ treatment interaction was statistically significant. Under non-irrigated conditions, the 'Ayvalık' exhibited greater ET than the 'Gemlik'. It can be seen therefore that the 'Ayvalık' olive cultivar possesses a more effective water transport mechanism and exhibits more resistance to water stress.

Changes in daily ET values are shown in Figure 1 for the 'Ayvalık' olive cultivar and in Figure 2 for the 'Gemlik' olive cultivar.

Daily ET curves of the 'Ayvalık' and 'Gemlik' cultivars followed a similar pattern in both years. The differences between daily ET values of the treatments 
Table 4. Total evapotranspiration (ET) values $\left(\mathrm{L} \mathrm{pot}^{-1}\right)$ of 'Ayvalık' and 'Gemlik' olive cultivars per treatment

\begin{tabular}{lccccc}
\hline \multirow{2}{*}{ Cultivar } & Year & \multicolumn{3}{c}{ Treatment } \\
\cline { 3 - 6 } & & I-100 & I-75 & I-50 & I-0 \\
'Ayvalık' & 2009 & $31.69 \mathrm{~A}$ & $25.11 \mathrm{~B}$ & $19.16 \mathrm{C}$ & $6.12 \mathrm{D}$ \\
& 2010 & $34.89 \mathrm{~A}$ & $28.38 \mathrm{~B}$ & $20.87 \mathrm{C}$ & $6.20 \mathrm{D}$ \\
& Mean & $33.29 \mathrm{Ab}$ & $26.75 \mathrm{Bb}$ & $20.02 \mathrm{Cb}$ & $6.16 \mathrm{Da}$ \\
\hline \multirow{2}{*}{ 'Gemlik' } & 2009 & $35.09 \mathrm{~A}$ & $27.65 \mathrm{~B}$ & $19.44 \mathrm{C}$ & $5.14 \mathrm{D}$ \\
& 2010 & $38.95 \mathrm{~A}$ & $31.06 \mathrm{~B}$ & $22.18 \mathrm{C}$ & $5.64 \mathrm{D}$ \\
& Mean & $37.02 \mathrm{Aa}$ & $29.35 \mathrm{Ba}$ & $20.81 \mathrm{Ca}$ & $5.39 \mathrm{Db}$ \\
\hline
\end{tabular}

Explanations under Table 3

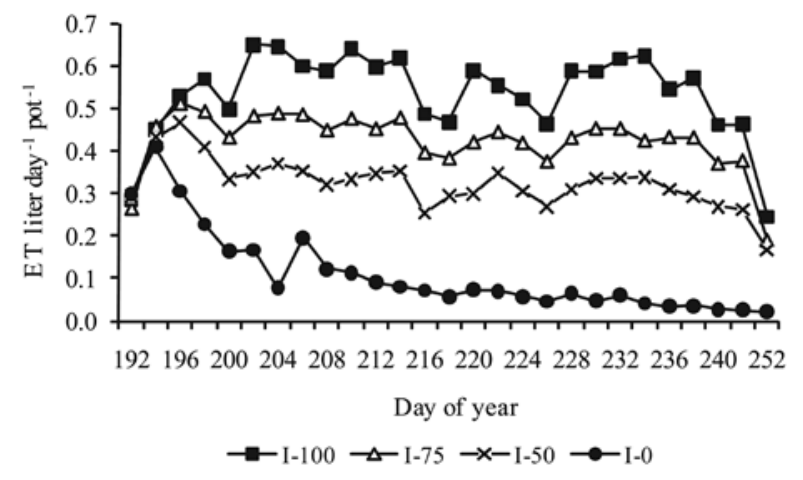

a

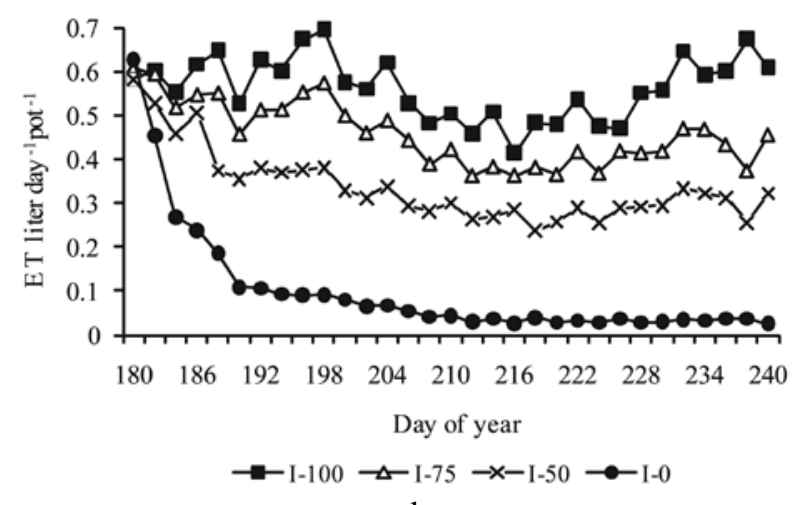

$\mathrm{b}$

Figure 1. Daily evapotranspiration (ET) values of 'Ayvalık' olive cultivar in 2009 (a) and 2010 (b)

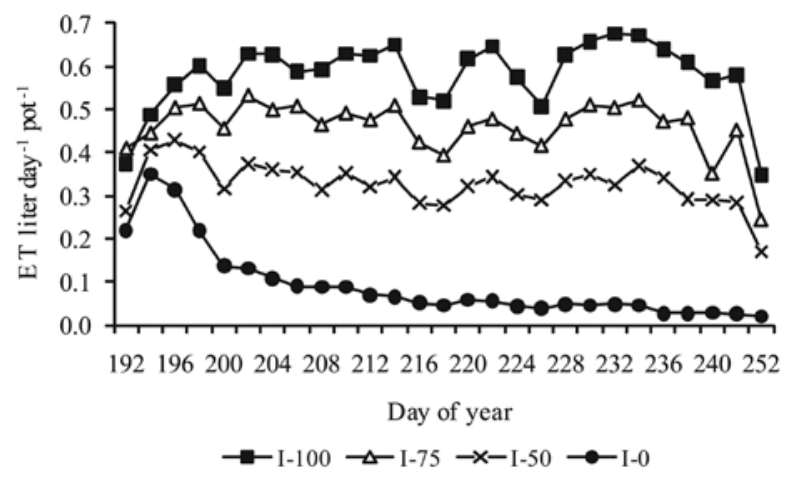

a

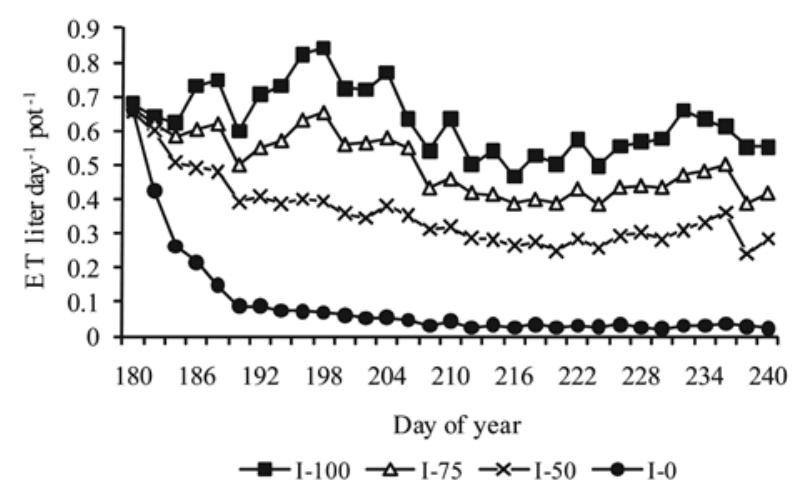

b

Figure 2. Daily evapotranspiration (ET) values of 'Gemlik' olive cultivar in 2009 (a) and 2010 (b)

began to increase after starting the water deficit. Daily ET values of the I-0 treatment in both cultivars began to decline rapidly and reached minimum level at the end of the experiment. The daily minimum and maximum ET values for the I-100 treatment in the 'Ayvalık' cultivar were found to be 0.24 and $0.65 \mathrm{~L} \mathrm{pot}^{-1}$ respectively in 2009 , and 0.41 and $0.69 \mathrm{~L} \mathrm{pot}^{-1}$ respectively in 2010 . These values were $0.35-0.68 \mathrm{~L} \mathrm{pot}^{-1}$ and $0.47-0.84 \mathrm{~L} \mathrm{pot}^{-1}$ respectively for the 'Gemlik' cultivar. The data obtained show that under non-stressed conditions, the daily ET values of 'Gemlik' seedlings are higher than those of 'Ayvalık' seedlings. The daily maximum ET values by year were obtained on $\mathrm{DOY}_{202}$ (22 July) and DOY ${ }_{198}$ (18 July) respectively in the 'Ayvalik' cultivar, and on DOY ${ }_{232}$ (21 August) and DOY $_{198}$ (18 July) in the 'Gemlik' cultivar.
Variation in the difference between leaf temperature and air temperature (Tc-Ta). Mean Tc-Ta values measured in the 'Ayvalık' and 'Gemlik' olive seedlings during the experiment are given in Table 5. As can be seen in Table 5, mean Tc-Ta values are between $-1.7^{\circ} \mathrm{C}$ and $0.9^{\circ} \mathrm{C}$ in the 'Ayvalık' cultivar, and between $-0.8^{\circ} \mathrm{C}$ and $1.9^{\circ} \mathrm{C}$ in the 'Gemlik' cultivar. While minimum values were observed in the I-100 (fullyirrigated) treatment, maximum values were obtained at I-0 (non-irrigated) treatment in both cultivars. The difference in Tc-Ta values of these treatments was $2.6^{\circ} \mathrm{C}$ for 'Ayvalık' and $2.7^{\circ} \mathrm{C}$ for 'Gemlik'. Akkuzu et al. (2010) reported a difference of $2.7^{\circ} \mathrm{C}$ between $\mathrm{Tc}-\mathrm{Ta}$ values in Memecik olive trees irrigated at $100 \%$ of crop evapotranspiration and those non-irrigated. Comparing 
these results, although the plant cultivar was not the same, the differences between Tc-Ta values of olive plants fully irrigated and non-irrigated were found to be very close to each other. In studies conducted in other countries, Jimenez-Berni et al. (2007) and Sepulcre-
Canto et al. (2009) reported that in well-irrigated and non-irrigated olive trees, the difference was around $2^{\circ} \mathrm{C}$. Testi et al. (2008) reported that different between canopy temperatures $(\mathrm{Tc})$ of non-stressed and stressed was about $6^{\circ} \mathrm{C}$ at about $1500 \mathrm{~h}$ in pistachio trees.

Table 5. Mean leaf temperature-air temperature (Tc-Ta) values $\left({ }^{\circ} \mathrm{C}\right)$ per treatment in 'Ayvalık' and 'Gemlik' olive cultivars

\begin{tabular}{cccccc}
\hline \multirow{2}{*}{ Cultivar } & Year & \multicolumn{3}{c}{ Treatment } \\
\cline { 3 - 6 } & & I-100 & I-75 & I-50 & I-0 \\
'Ayvalık' & 2009 & $-2.3 \mathrm{D}$ & $-1.4 \mathrm{C}$ & $-0.6 \mathrm{~B}$ & $0.4 \mathrm{~A}$ \\
& 2010 & $-1.0 \mathrm{D}$ & $-0.3 \mathrm{C}$ & $0.5 \mathrm{~B}$ & $1.4 \mathrm{~A}$ \\
& Mean & $-1.7 \mathrm{Db}$ & $-0.9 \mathrm{Cb}$ & $-0.1 \mathrm{Bb}$ & $0.9 \mathrm{Ab}$ \\
\hline \multirow{2}{*}{ 'Gemlik' } & 2009 & $-1.0 \mathrm{C}$ & $-0.5 \mathrm{C}$ & $0.5 \mathrm{~B}$ & $2.2 \mathrm{~A}$ \\
& 2010 & $-0.6 \mathrm{C}$ & $-0.1 \mathrm{C}$ & $0.6 \mathrm{~B}$ & $1.5 \mathrm{~A}$ \\
& Mean & $-0.8 \mathrm{Ca}$ & $-0.3 \mathrm{Ca}$ & $0.6 \mathrm{Ba}$ & $1.9 \mathrm{Aa}$ \\
\hline
\end{tabular}

Notes. Capital letters refer to differences between irrigation treatments; lower letters refer to differences between cultivars. The cultivar $\times$ treatment interaction was statistically significant.

The mean vapour pressure deficit obtained was 3.4 at the time of measurement during the experiment. The mean ambient air temperature was $33.1^{\circ} \mathrm{C}$ in 2009 and $34.0^{\circ} \mathrm{C}$ in 2010 . The mean air temperature in August 2010 was $2.4^{\circ} \mathrm{C}$ higher than that in August 2009 (Table 1). Due to differences in temperature, Tc-Ta values in the second year were higher than in the first year in all treatments (except for I-0 in the 'Gemlik' cultivar) in both cultivars.

Jackson et al. (1977) stated that for many plants when that plant is transpiring fully, the leaf temperature is $1-4^{\circ} \mathrm{C}$ below air temperature. Jackson (1982) reported that plant temperature was generally lower than ambient air temperature and canopy temperature in the stress treatment, most likely because of the cooling effects of transpiration. Likewise, in the present study, the mean Tc-Ta values of the I-100 and I-75 treatments were lower than the ambient air temperature in both years.

When Tc-Ta values were evaluated statistically, the values of all the treatments were different from each other in the 'Ayvalık' cultivar. In the 'Gemlik' cultivar, while Tc-Ta values of the I-100 and I-75 treatments were in the

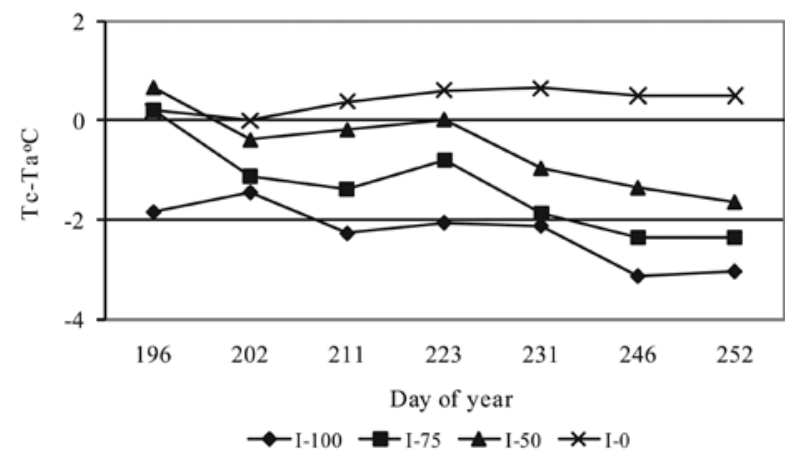

a same group, the other treatments were in different groups (Table 5). Comparing the treatments of each cultivar, TcTa values of all treatments in the 'Ayvalik' cultivar were lower and statistically different from the 'Gemlik' cultivar. Accordingly, although evapotranspiration of 'Gemlik' seedlings was higher than that of 'Ayvalık' seedlings, 'Gemlik' seedlings were more affected by ambient air temperature and thus leaf temperatures were higher. Even in non-stressed cases, it was seen that the leaf temperatures of 'Gemlik' seedlings were higher than those of 'Ayvalık' seedlings. This shows that although the plant species are the same, leaf temperature may change depending on cultivar characteristics.

From Figures 3 and 4 showing the Tc-Ta values of 'Ayvalık' and 'Gemlik' cultivars during the experiment, it can be seen that the curve of the I-100 treatment is generally at the lowermost, however, the curve of the I- 0 treatment is generally at the uppermost in all measurements. It is seen that Tc-Ta values of treatments that are close to each other are nested on some measurement days.

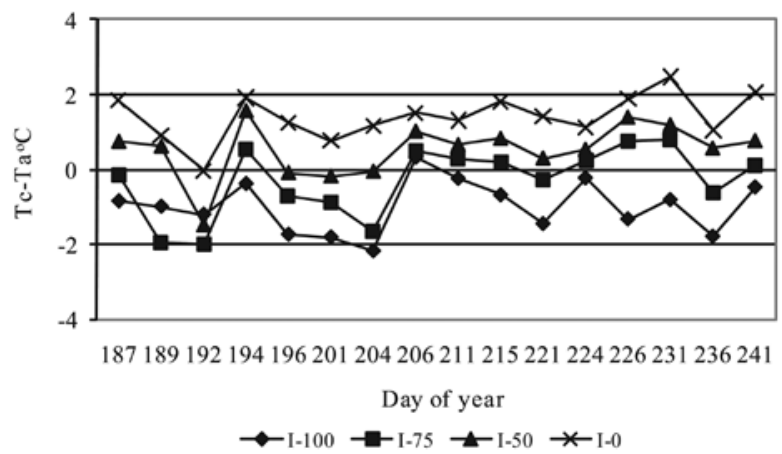

$\mathrm{b}$

Figure 3. Leaf temperature-air temperature (Tc-Ta) values of 'Ayvalık' olive cultivar in 2009 (a) and 2010 (b) 


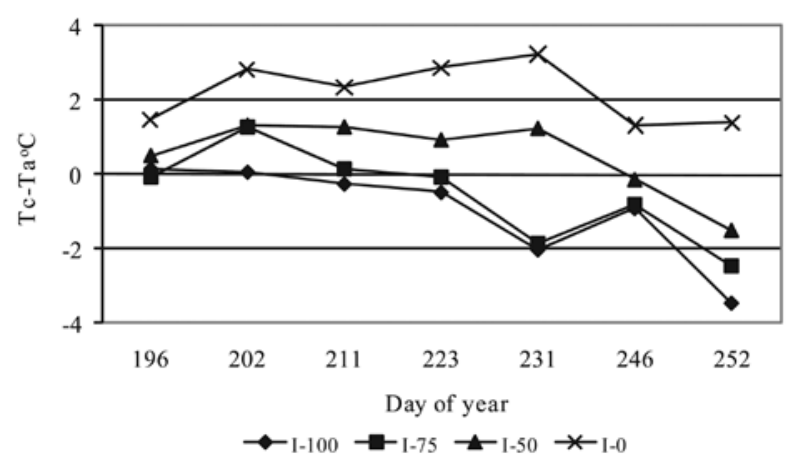

a

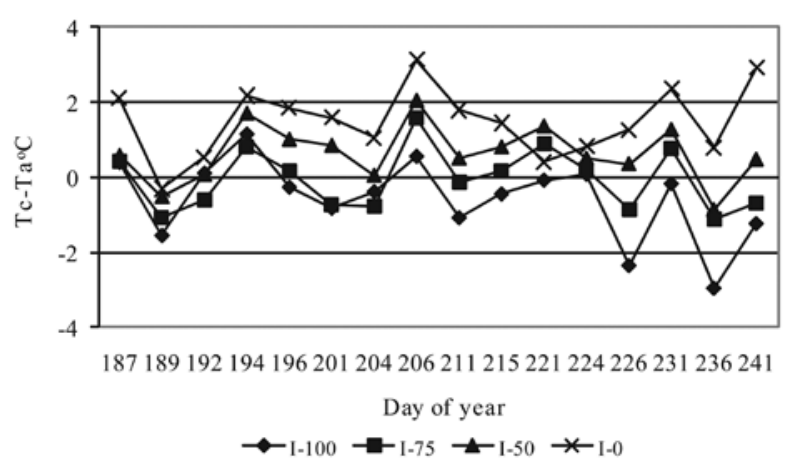

b

Figure 4. Leaf temperature-air temperature (Tc-Ta) values of 'Gemlik' olive cultivar in 2009 (a) and 2010 (b)

The reason for this stemmed from ambient climate conditions at the time of measurement. Similarly, wind speed was reported to be the primary factor causing erroneous estimation of leaf temperature and hence Tc-Ta values (O'Toole, Hatfield, 1983; Gardner et al., 1992).

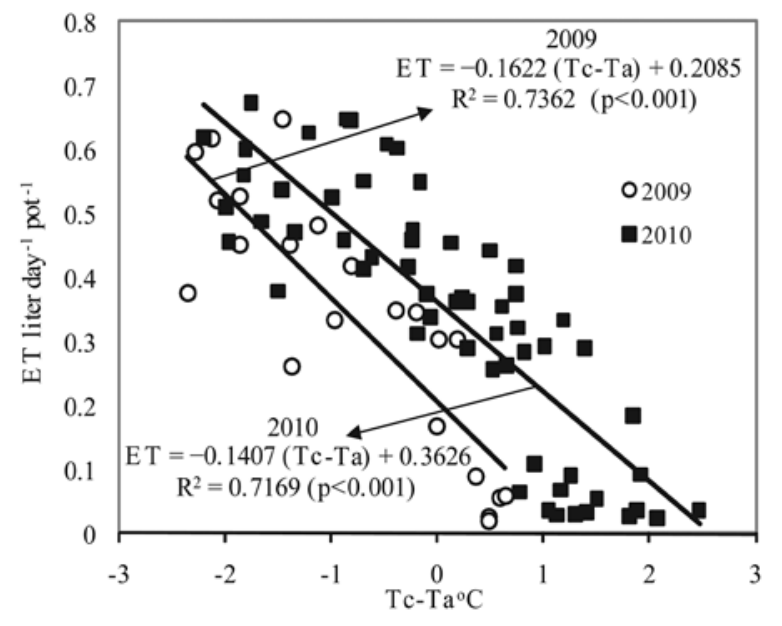

a
Relationship between daily ET and Tc-Ta. Regression analysis between Tc-Ta and daily ET during the experiment in 2009 and 2010 is shown in Figure 5a for the 'Ayvalık' cultivar and in Figure 5b for the 'Gemlik' cultivar.

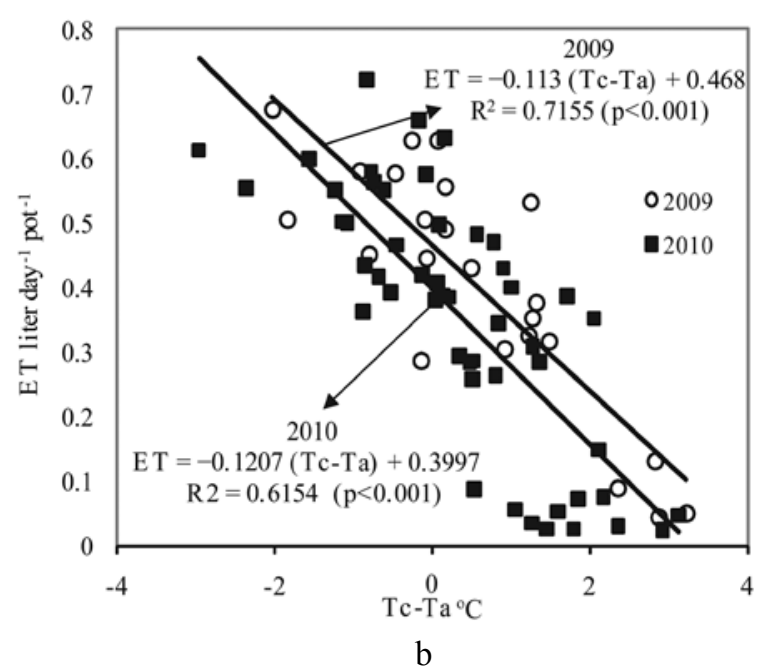

Figure 5. Relationship between evapotranspiration (ET) and leaf temperature-air temperature (Tc-Ta) in 'Ayvalık' (a) and 'Gemlik' (b) olives

The Tc-Ta values increased linearly depending on decrease of ET in both cultivars. Jones and Leinonen (2003) reported that leaf temperature declines as stomata open and evaporation rates increase, and measurements of leaf temperature can be used to give an indication of changes in stomatal conductance and transpiration rates.

The coefficients of determination $\left(\mathrm{R}^{2}\right)$ between Tc-Ta and daily ET were found to be 0.74 and 0.72 respectively for the 'Ayvalık' olive cultivar and 0.72 and 0.62 respectively for the 'Gemlik' olive cultivar in 2009 and 2010. All $\mathrm{R}^{2}$ values were statistically significant at $p<$ 0.001 . In a study on the use of the infrared thermometer for water stress detection in the faba bean, the correlation between Tc-Ta and ET at mid-stress interval was nonsignificant. However, the correlation between Tc-Ta and ET $(r=0.94-0.98)$ at the end of the stress interval was highly significant (Ahmed et al., 2006). Patel et al. (2001) found that Tc-Ta was significantly $(P \leq 0.05)$ related to the ET of the pigeon pea. Grey (2010) stated that the regression coefficient $\left(\mathrm{R}^{2}\right)$ between evapotranspiration (ET) and mean leaf temperature of tomato was 0.648.

\section{Conclusions}

1. The irrigation water requirements of 'Gemlik' cultivar which is consumed as black table olives are greater than those of 'Ayvalık' which is consumed as olive oil under non-stressed conditions. For this reason, in areas where water supply is short and irrigation facility is limited, 'Ayvalık' cultivar can be grown.

2. Difference between leaf temperature and air temperature (Tc-Ta) values decreased depending on increase of irrigation water applied and accordingly evapotranspiration. Minimum and maximum values were obtained for the non water-stressed and fully waterstressed seedlings respectively. Mean difference between Tc-Ta values of these seedlings was $2.7^{\circ} \mathrm{C}$.

3. Although evapotranspirations of 'Gemlik' seedlings were higher than those of 'Ayvalık' seedlings, 
Tc-Ta values for all treatments in the 'Ayvalık' cultivar were lower compared with 'Gemlik' cultivar. In a sense, 'Gemlik' olive seedlings were more affected by ambient air temperature. Although leaf temperatures of 'Ayvalik' seedlings were affected by mild water-stress, leaf temperatures of 'Gemlik' seedlings were affected after a moderate stress level.

4. This study showed that leaf temperatures changed depending on evapotranspiration in olive seedlings. Significant negative linear relationships were obtainedbetween Tc-Tavaluesanddailyevapotranspiration (ET) in both olive cultivars. Accordingly, it can be said that Tc-Ta can potentially be used to determine daily ET. However, relationships between Tc-Ta values and ET should be also investigated for the other olive cultivars.

\section{Acknowledgements}

The author is indebted to Assoc. Prof. Dr. Erhan Akkuzu and Dr. Unal Kaya for organizational support and their help with field work.

Received 30052012

Accepted 14122012

\section{References}

Ahmed M. F., Dawi I., Ibrahim O. H. 2006. Use of infrared thermometer for water stress detection in faba bean. Sudan Journal of Agricultural Research, 6: 43-51

Akkuzu E., Camoglu G., Kaya U. 2010. Diurnal variation of canopy temperature differences and leaf water potential of field-grown olive trees (Olea europaea L. cv. Memecik). The Philippine Agricultural Scientist, 93 (4): 399-405

Arsel H., Sefer F. 2006. Bazı önemli yerli ve yabanci çeşitlerin bölgelerimize adaptasyonu (Çalıştay) / Gül M., Umdu S. (eds). Ulusal Zeytin ve Zeytinyağı Sempozyumu ve Sergisi, TMMOB Kimya Mühendisleri Odası Yayınları, p. 539-549 (in Turkish)

Aşık Ş., Çamoğlu G., Akkuzu E., Kaya Ü., Şahin M. 2010. Zeytinde (Olea europaea L. cv. Memecik) Farklı sulama düzeylerinin vejetatif gelişime ve verime etkisi. Tarım Bilimleri Araştırma Dergisi, 3 (2): 33-39 (in Turkish)

Canözer Ö. 1991. Standart zeytin çeşitleri kataloğu. T. C. Tarım ve Köyişleri Bakanlığı. Mesleki Yayınlar Genel, 334 (16): 107 (in Turkish)

Chartzoulakis K., Bosabalidis A., Patakas A., Vemmos S. 2000. Effects of water stress on water relations, gas exchange and leaf structure of olive tree. Acta Horticulturae, 537: 241-247

FAO. 2011. Food and Agriculture Organization of the United Nations. <http://faostat.fao.org/site/339/default.aspx> [accessed 0102 2012]

Fuchs M., Tanner C. B. 1966. Infrared thermometry of vegetation. Agronomy Journal, 58: 597-601 http://dx.doi.org/10.2134/agronj1966.0002196200580006 $0014 \mathrm{x}$

Gardner B. R., Nielsen D. C., Shock C. C. 1992. Infrared thermometry and the crop water stress index. II. Sampling procedures and interpretation. Journal of Production Agriculture, 5 (4): 466-475 http://dx.doi.org/10.2134/jpa1992.0466

Grey S. N. 2010. Monitoring the simultaneous response of various water status indicators for use in the irrigation scheduling and drought stress detection of a greenhouse tomato crop. Master of Science thesis, University of Zimbabwe, $132 \mathrm{p}$.

Jackson R. D. 1982. Canopy temperature and crop water stress. Advances in Irrigation / Daniel H. (ed.). New York, USA, p. $43-85$

Jackson R. D., Idso S. B., Reginato R. J., Ehrler W. L. 1977. Crop temperature reveals stress. Crop Soils, 29: 10-13

James L. G. 1988. Principles of farm irrigation systems design. New York, USA, 543 p.

Jones H. G. 1999. Use of thermography for quantitave studies of spatial and temporal variation of stomatal conductance over leaf surfaces. Plant, Cell and Environment, 22: $1043-1055$

http://dx.doi.org/10.1046/j.1365-3040.1999.00468.x

Jones H. G., Leinonen I. 2003. Thermal imaging for the study of plant water relations. Journal of Agricultural Meteorology, 59: $205-217$ http://dx.doi.org/10.2480/agrmet.59.205

Jimenez-Bello M. A., Ballester C., Castel J. R., Intrigliolo D. S. 2011. Development and validation of an automatic thermal imaging process for assessing plant water status. Agricultural Water Management, 98: 1497-1504

Jimenez-Berni J. A., Zarco-Tejada P. J., Fereres E., SepulcreCanto G., Testi L., Iniesta F., Villalobos F. J., Orgaz F., Goldhamer D. A., Salinas M. 2007. Estimation of ET on discontinuous crop canopies using high resolution thermal imagery: IEEE International Geoscience and Remote Sensing Symposium, IGARSS. Barcelona, Spain, p. 3249-3252 http://dx.doi.org/10.1016/j.agwat.2011.05.002

Metheney P. D., Ferguson L., Goldhamer D. A., Dunai J. 1994. Effects of irrigation on Manzanillo olive flowering and shoot growth. Acta Horticulturae, 356: 168-171

O'Toole J. C., Hatfield J. L. 1983. Effect of wind on the crop water stress index derived by infrared thermometry. Agronomy Journal, 75: 811-817 http://dx.doi.org/10.2134/ agronj1983.00021962007500050019x

Öztürk F., Yalçın M., Diraman H. 2009. An overview on the olive oil economy of Turkey. Electronic Journal of Food Technology, 4 (2): 35-51

Patel N. R., Mehta A. N., Shekh A. M. 2001. Canopy temperature and water stress quantification in rainfed pigeonpea (Cajanus cajan (L.) Millsp.). Agricultural and Forest Meteorology, 109 (3): 223-232 http://dx.doi.org/10.1016/S0168-1923(01)00260-X

Sdoodee S., Kaewkong P. 2006. Use of an infrared thermometer for assessment of plant water stress in neck orange (Citrus reticulata Blanco). Songklanakarin Journal of Science Technology, 28 (6): 1161-1167

Sepulcre-Canto G., Zarco-Tejada P.J., Sobrino J. A., Berni J. A.J., Jimenez-Munoz J. C., Gastellu-Etchegorry J. P. 2009. Discriminating irrigated and rainfed olive orchards with thermal ASTER imagery and DART 3D simulation. Agricultural and Forest Meteorology, 149: 962-975 http://dx.doi.org/10.1016/j.agrformet.2008.12.001

Testi L., Goldhamer D. A., Iniesta F., Salinas M. 2008. Crop water stress index is a sensitive water stress indicator in pistachio trees. Irrigation Science, 26: 395-405 http://dx.doi.org/10.1007/s00271-008-0104-5

Xiloyannis C., Dichio B., Nuzzo V., Celano G. 1999. Defense strategies of olive against water stress. Acta Horticulturae, 474: $423-426$ 
ISSN 1392-3196

Zemdirbyste-Agriculture, vol. 100, No. 1 (2013), p. 91-98

UDK 635.9:631.67:631.526 / DOI 10.13080/z-a.2013.100.012

\title{
Drègmès stygiaus įtaka europinio alyvmedžio (Olea europaea L.) dviejų veislių evapotranspiracijai ir lapų temperatūrai
}

\author{
G. Çamoğlu \\ Canakkale Onsekiz Mart universitetas, Turkija
}

\begin{abstract}
Santrauka
Vegetaciniai eksperimentai atlikti su dviem europinio alyvmedžio (Olea europaea L.) veislèmis 'Ayvalık' ir 'Gemlik'. Matuota evapotranspiracija (ET) ir lapų temperatūra, augalams sudarius visiško aprūpinimo drègme ir drègmès stokos sąlygas. Vegetacinis bandymas vykdytas lauko sąlygomis 2009 ir $2010 \mathrm{~m}$. Bandymą sudarè keturi variantai: 1) be drègmès stygiaus, 2) nedidelis drègmès stygius, 3) vidutinis drègmès stygius ir 4) visiškas drègmès stygius. Kiekvieno augalo lapų (Tc) ir aplinkos oro (Ta) temperatūra matuota vidurdienị infraraudonujų spindulių termometru bei psichrometru ir apskaičiuotas temperatūrų skirtumas (Tc-Ta). Nustatyta, kad veislès 'Gemlik' alyvmedžių drèkinimo poreikis buvo didesnis nei veislès 'Ayvalık'. Tc-Ta abiem veislëms didžiausias buvo stokojant drėgmès, mažiausias - visiškai aprūpinus drėgme. Visuose variantuose veislès 'Gemlik' augalų Tc-Ta buvo didesnis nei veislès 'Ayvalık'. Ryšys tarp Tc-Ta ir ET buvo linijinis, o determinacijos koeficientai (pagal linijinès regresijos analizę $\mathrm{R}^{2}=0,72-0,74$ veislei 'Ayvalık', $\mathrm{R}^{2}=0,62-0,72$ veislei 'Gemlik') abiem veislèms buvo esminiai esant $p<0.001$. Tyrimas parodè, kad abiejų veislių alyvmedžių lapų temperatūra kito priklausomai nuo ET ir kad augalų lapų ET matuoti infraraudonųjų spindulių termometrą galima naudoti atliekant kasdieninius matavimus.
\end{abstract}

Reikšminiai žodžiai: alyvmedis, 'Ayvalık', ‘Gemlik’, drègmès stresas, drèkinimas, lapų temperatūra. 